\title{
Trans-disciplinary research on religious formations in urban Africa: Towards liberative methodological approaches
}

\begin{tabular}{|c|c|}
\hline \multicolumn{2}{|c|}{$\begin{array}{l}\text { Authors: } \\
\text { Stephan F. de Beer } \\
\text { R. Drew Smith }{ }^{1,2,3} \\
\text { Jacob Manyaka } a^{1,2,4}\end{array}$} \\
\hline \multicolumn{2}{|c|}{$\begin{array}{l}\text { Affiliations: } \\
{ }^{1} \text { Centre for Contextual } \\
\text { Ministry, Faculty of Theology, } \\
\text { University of Pretoria, } \\
\text { South Africa }\end{array}$} \\
\hline \multicolumn{2}{|c|}{$\begin{array}{l}{ }^{2} \text { Department of Practical } \\
\text { Theology, Faculty of } \\
\text { Theology, University of } \\
\text { Pretoria, South Africa }\end{array}$} \\
\hline \multicolumn{2}{|c|}{$\begin{array}{l}\text { 3Pittsburgh Theological } \\
\text { Seminary, United States }\end{array}$} \\
\hline \multicolumn{2}{|c|}{$\begin{array}{l}{ }^{4} \text { Willow Manor Christian } \\
\text { Centre, Nellmapius, Phenyo } \\
\text { Christian College, } \\
\text { South Africa }\end{array}$} \\
\hline \multicolumn{2}{|c|}{$\begin{array}{l}\text { Research Project Registration: } \\
\text { Project Leader: S.F. de Beer } \\
\text { Project Number: } 86233689\end{array}$} \\
\hline \multicolumn{2}{|c|}{$\begin{array}{l}\text { This research is part of the } \\
\text { research project, 'Social } \\
\text { Justice and Reconciliation', } \\
\text { which is directed by Dr } \\
\text { Stephan de Beer, Director of } \\
\text { the Centre for Contextual } \\
\text { Ministry and member of the } \\
\text { Department of Practical } \\
\text { Theology, Faculty of Theology, } \\
\text { University of Pretoria. }\end{array}$} \\
\hline \multicolumn{2}{|c|}{$\begin{array}{l}\text { Corresponding author: } \\
\text { Stephan de Beer, } \\
\text { stephan.debeer@up.ac.za }\end{array}$} \\
\hline \multicolumn{2}{|c|}{$\begin{array}{l}\text { Dates: } \\
\text { Received: } 08 \text { Jun. } 2017 \\
\text { Accepted: } 18 \text { Aug. } 2017 \\
\text { Published: } 27 \text { Nov. } 2017\end{array}$} \\
\hline \multicolumn{2}{|l|}{ Read online: } \\
\hline 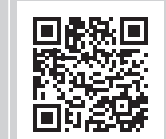 & $\begin{array}{l}\text { Scan this QR } \\
\text { code with your } \\
\text { smart phone or } \\
\text { mobile device } \\
\text { to read online. }\end{array}$ \\
\hline
\end{tabular}

In this article, we are exploring a methodological approach to research on faith and religious expressions in urban Africa. We are committed to trans-disciplinary work that pursues research methods mutually liberating for researchers, co-researchers and community participants and that results in long-term benefits and strengthened agency on the part of the host communities. Our reflections in this article are based on a collaborative research project ${ }^{1}$ in two regions of Pretoria, Tshwane ${ }^{2}$ - Pretoria Central and Mamelodi East - in which we explore how religious innovation and competition in and amongst churches contribute to the healing or perpetuation of urban fractures.

\section{Introduction}

In this article, we are describing in an exploratory manner the methodological considerations for a specific research project entitled 'Religious innovation and competition amidst social and demographic change: Pretoria case study'. The primary interest of the project is to explore what the religious innovations and competitions generating within socially dynamic African urban contexts reveal about the resilience, creativity and agency of African communities of faith, and whether processes of religious innovation and competition contribute to the healing or perpetuation of urban fractures. It did so through a comparative reflection on two different regions in Pretoria, the City of Tshwane.

A further consideration, emerging only as the project unfolded, is a critical (and self-)evaluation of standard theological and sociological languages, frameworks and methodologies as tools relevant to the research assessments being undertaken by our co-researchers in the communities under investigation. Through this project, we have arrived at a place where we are interested to explore more deeply the possibility of liberating, trans-disciplinary research methodologies that will simultaneously generate collaborative knowledge of faith and religious expressions in urban African contexts, whilst allowing co-researchers to assert their own agency and build their own capacity for critical urban engagement.

\section{Urban Africa: Faith and religious responses and expressions}

The research focused on two spatially distinct municipal regions in Pretoria marked by urban change and vulnerability. As the administrative capital of South Africa, hosting more than 90 diplomatic missions from across the world, Pretoria is receiving both cross-border and ruralurban migrants on a daily basis. The two regions chosen for this research are marked by a concentration of migration, resulting in ongoing urban change, different forms of informality in terms of dwellings, the local economy and religious expression, but also expressing itself in concentrated forms of vulnerability because of landlessness, homelessness, informal housing, unemployment and poverty.

\footnotetext{
1.Our collaborative research project was entitled 'Religious innovation and competition amidst urban social change: a Pretoria case study'.

2.Pretoria is the administrative capital of South Africa and still the official name of what is now the City of Tshwane Metropolitan Municipality.

Note: This article forms part of a collaborative research project entitled 'Religious innovation and competition amidst urban social change: a Pretoria case study'. The project was funded by the Templeton Foundation as part of an African-wide enquiry on 'Christianity and social change in contemporary Africa'.

The project is also a sub-theme of the 'Faith in the City' research project, hosted by the Centre for Contextual Ministry in the Faculty of Theology, University of Pretoria.

How to cite this article: De Beer, S.F., Smith, R.D. \& Manyaka, J., 2017, 'Trans-disciplinary research on religious formations in urban Africa: Towards liberative methodological approaches', HTS Teologiese Studies/Theological Studies 73(3), a4693. https://doi.org/10.4102/hts.v73i3.4693

Copyright: @ 2017. The Authors. Licensee: AOSIS. This work is licensed under the Creative Commons Attribution License.
} 
As part of rapid urban change, the religious landscapes in these areas changed considerably, and religious innovation and competition have been expressed in various ways. Pretoria Central is a largely commercial zone adjacent to areas of concentrated, affordable flats. Pretoria Central's commercial properties have become locations of choice for newly emerging congregations who buy or rent commercial spaces that are then converted to church worship facilities. There are dozens of these emerging congregations throughout Pretoria Central, with new congregations emerging frequently. Although not all of these congregations are equally robust and enduring, most are quite religiously vibrant and organisationally innovative. Some have grown to encompass large memberships of 500 or more persons. Within Pretoria Central, there are also a much smaller number of long-established congregations founded decades ago, with steepled church buildings and originally exclusively white memberships. Most of these congregations have shifted dramatically in the demographics of their parishioners, as the massive influx of black migrants and immigrants into Pretoria Central have become part of these longstanding congregations.

Quite apart from Pretoria Central (both geographically and structurally) is Mamelodi East, a township consisting of several divisions. It includes Phomolong (an informal settlement comprised mostly of 'shack' housing), Extension 4 (a formal settlement composed of private market housing purchased through loans), Extension 5 (which started as an informal settlement, more recently interspersed with more elaborate 'permanent' houses) and Extension 6 (a formal settlement composed of more 'permanent' government-built or RDP housing ${ }^{3}$ and more elaborate privately built housing). The churches in Mamelodi East have reflected their economic structural surroundings. The church in Phomolong, which we had a focus group with, occupies a shack. In Extension 4 (a context where most of the residents are professionals), most congregations have built impressive buildings. Congregations in Extension 5 are mostly at the stage of acquiring property sites, with only a few having actually constructed buildings at this point. The two churches found in Extension 6 are operating inside the yard space of each pastor's home. One church built a shelter around the RDP house of the pastor. They have their church services there. This is because there is shortage of property sites for churches in Extension 6.

Although life in Mamelodi East is structured more around neighbourhoods composed of houses rather than around concentrations of high-rise flats and commercial real estate, what Mamelodi East does share in common with Pretoria Central is a dynamic of rapid change, driven by population movement (both influxes and out-migrations). Often, urban migration is accompanied by deep and multifaceted forms of urban vulnerability. Pretoria Central provides greater access

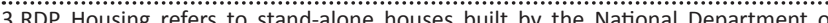
Human Settlements as part of the Reconstruction and Development Programme (RDP) settleme (RDP), a national socio-economic programme adopted in 1994 by the Nationa Government to address the socio-economic legacy of apartheid. A huge drive was launched to provide free houses for poor families across the country. to transnational migrants, whilst Mamelodi East is home to migrants mostly coming from all over South Africa. Mamelodi East experienced the devastation of xenophobic attacks against transnational migrants in the past decade, whilst less of that occurred in the more cosmopolitan neighbourhoods of Pretoria Central, until recently when in February 2017, small businesses and houses of foreign migrants were torched in Pretoria West, the neighbourhood directly adjacent to Pretoria Central.

It could, perhaps, be said that the primary constant within urban settings in the global South is change: socio-economicspatial-cultural-religious-generational-political change. The realities of urban change, informality and vulnerability and the relationship between these dynamics and such matters as religious innovation and competition offer unique research challenges. The concept of social innovation has in the past two decades gained much ground, with an emphasis on social entrepreneurship and on finding ways to create economically and environmentally viable solutions for some of the world's greatest social problems. This thinking has been applied to problems ranging from homelessness and health to build technologies, access to water and sanitation, alternative educational models, earth keeping and peace building.

Innovation, however, should be considered critically in relation to fragmentation. The research project was attentive to whether pursuits of religious innovation (and the religious competition sometimes resulting from these pursuits) gave rise to community building languages or consciousness, or instead perpetuated apathy and exclusion. Similarly, competition is a concept that elicited diverse responses from different churches both in Pretoria Central and in Mamelodi. The notion of urban competition, whilst becoming a dominant vision amongst urban managers, marking the way in which cities outperform rival cities economically (cf. Huchzermeyer 2011:48-68), it also became the way by which cities exclude the poor, focusing investment rather on high-level infrastructure projects seeking to attain global status, often at the expense of appropriate investment in social infrastructure, social welfare or services, or the environment (cf. Huchzermeyer 2011:4950). Critics of the 'competition' discourse demonstrate the corporatisation and commodification of cities at the expense of vulnerable urban communities.

Segregation and injustices have been spatially mediated in South African cities. There exists a certain socio-spatial hierarchy in urban South Africa which has determined the flow and mobility of people between regions in the city. This is also evident in the way Mamelodi East and Pretoria Central relate to each other. Mamelodi East is approximately 25 miles east of Pretoria Central, yet from the apartheid era to the present, Mamelodi East has functioned as a dumping site for people displaced from other parts of the city. A subtheme explored in our research was the extent to which religious innovation and religious competition responded to issues of spatiality, spatial disparities and socio-spatial urban change. Did local churches contribute to the healing or perpetuation 
of urban spatial fractures? How do churches respond to urban policies and urban competition that only deepen the fragmentation? The two contexts provide an interesting research contrast in terms of location, social fibre, infrastructure and relative centrality or marginality.

\section{Epistemological and methodological shifts and religion in African cities}

Researchers have given insufficient attention to religious responses to urbanisation and urban change in the global South, and particularly in Africa. As a result, too often there is over-reliance on the global North with respect to urban public theology, urban research approaches and social scientific analysis of African religion. As such, this research frequently fails to capture, articulate and share knowledge produced in and by urban Africans.

In an article on performing urban public theology in (South) Africa, De Beer and Swart (2014) proposed as a priority for consideration more thorough conceptual and empirical work on 'actors of faith in relation to urban social life'. They detect, however, tentatively signs of a 'religious turn' in South African urban enquiry, which acknowledges that the urban reality cannot be sufficiently understood without an understanding of religious expressions accompanying. Drawing upon analysis by Rakodi (2014) and Winkler (2008a; 2008b), they propose for theologians to take cues from those outside the disciplines of theology for an appreciation of the important role of faith and religion in urban Africa today.

Our research here is driven by an interest in developing knowledge and understanding about religious expressions emerging in urban Africa, but also by an interest in developing and sharing resources for equipping religious practitioners to engage in appropriate, critical, liberating, constructive and community-enhancing ways with their urban realities. Nonetheless, our research locates against a backdrop of an emerging body of knowledge known as 'southern urbanisms', which articulates urban forms, innovations and knowledge as they are coproduced in the cities of the global South. Massive urban in-migration accompanied by informality and distinctive forms of urbanity less familiar in the global north demand not only new knowledge but also new ways of generating or constructing knowledge. Pieterse (2014:1) highlights the politics of knowledge production: critical questions should be asked as to whose knowledge shapes the city (cf. De Beer 2014), with what purpose knowledge is being generated (Pieterse 2014:1) and how to construct decolonising knowledge in urban Africa.

'Southern urbanisms' represent an epistemological shift and epistemological practices that are at once intentionally resisting colonial or neocolonial forms of urbanity or knowledge production, whilst seeking to discern and construct practices of knowledge production that will be radically collaborative, acknowledging the existence of a range of actors who are, through their everyday practices, shaping city spaces through formal and informal politics'.
Pieterse (2014:1) further describes it as the search 'for a conceptual frame that can appreciate the agency of ordinary people amid vast oppressive machines and economic patterns of uneven development'. Framed in such a way provides our cue for considering 'liberating, transdisciplinary research methodologies' in relation to faith and religious expressions in urban Africa. It also speaks about an approach to the research that acknowledges the inherent dignity and value of the communities and people being researched or participating as co-researchers.

How can we do research in this space that will invite, affirm and appreciate existing knowledge residing in faith communities; which methods will best facilitate a just coproduction of knowledge; and how can the research process itself build agency in ways that could possibly contribute to liberating processes for both co-researchers as well as the faith communities or urban neighbourhoods in which they are present? In this project, the possible agency of faith or religious expressions, as found in churches in two urban regions of Pretoria, was considered. We are interested, both conceptually and empirically, to discover in which ways churches, faith-based organisations or religion at large contribute to the healing or perpetuation of urban fractures. This project has helped identify gaps in our own conceptual and methodological frameworks but also inspired us to journey deeper in both regards.

Part of the methodological and disciplinary tussle into which this project waded is related to perceived conflicts or complementariness between theological and sociological investigative tools. Theologian John Milbank's (2006) book, Theology and Social Theory: Beyond Secular Reason, challenges long held enlightenment and post-enlightenment orthodoxies pertaining to the social sciences as a superior form of analysis to theological analysis, a generalisation based upon the former's presumably more rational basis. Milbank argues that the concessions to this thinking have resulted in the idea that not only the social realm but also the religious realm is best interpreted through the lens of social scientific analysis, which is something Milbank believes to be an 'unwarranted' conclusion especially on the part of the theological community, whose interpretive tools he believes to be no less rational than those of social scientists (Milbank 2006:2). Nevertheless, an argument outlined in sociologist Peter Berger's (1967) text, The Sacred Canopy: Elements of a Sociological Theory of Religion looms large on these matters: 'Sociology ... raises questions for the theologian to the extent the latter's positions hinge on certain socio-historical presuppositions', writes Berger, 'and such presuppositions are particularly characteristic of theological thought in the Judaeo-Christian orbit' (Berger 1967:181).

What these conflicting positions demonstrate at the very least is that questions over what are best observational and interpretive methods in the study of religion are far from settled amongst scholars. As instructive as the intellectual considerations raised on either side of this debate may be for the furtherance of sound scholarly practices, the staking out 
of epistemological claims within scholarly realms of intellectual discourses and orthodoxies may still leave scholars far afield of vantage points from which to adequately interpret the social and religious dynamics transpiring and transforming on the ground and in real time - the dynamics which the conceptual languages and frameworks embraced within scholarly circles may not capture.

Both sociology and theology provide valuable descriptive methods useful for identifying and classifying observable religious dynamics and actions and for attempting to explain motivations behind those dynamics and actions, but religious dynamics can also prove particularly elusive to observation -especially where there may not be an agreement between the observer and those being observed about what might be classified as 'religious'. In the fluid realm of the 21st century urban religion in Africa, this is especially challenging, given a vast range of informal and newly forming religious activities and practices operating out of sight or sometimes hidden in plain view. When researchers are guided by fixed categories and definitions of religious practice, including formal institutional definitions of 'church' premised on western ideas of material culture, many aspects of actual religious life and practice within dynamic, innovative religious contexts can be easily misinterpreted or missed altogether.

The project here followed a trans-disciplinary research approach, merging insights from the social sciences and theology (cf. also Hankela 2014; Rakodi 2014), structuring the research around the contextual praxis cycle of Holland and Henriot (1983) and opting for a qualitative research methodology. In order to do justice to the research objectives, in particular the intentional benefits envisaged for the communities in which the research is taking place (the city centre of Pretoria and the largely informal settlements of Mamelodi East), efforts at diverse and culturally appropriate research methods were considered and creatively interwoven.

For the purpose of gathering information and knowledge about the different communities, the research team has made use of mapping, surveys and focus groups, and in order to create innovative spaces that can go beyond simply information extraction to potentially facilitate in-depth conversation and participatory construction of new knowledge, open space technology - World Café style conversation or the circle - has also been used.

The mapping process was used to locate churches in both regions, and to locate ourselves in the research. It provided initial entry into the community, and the churches mapped were then approached to participate in the research project through filling in survey forms. The survey provided us with rich baseline information and a good overall sense - or bird eyes view - of what transpired in churches in the two regions: in terms of numbers, demographic information, priorities, ministry activities as well as perceived challenges as seen through the lenses of participating churches. Based on the survey, we then identified churches that were willing to participate in more in-depth focus group conversations.
These churches were selected in a way that could represent a diversity of church traditions, but also a mix of more established or traditional churches, on the one hand, and emerging or migrant churches, on the other hand.

The World Café was employed as a research method, rather experimentally, both as an attempt to build ownership for the process and to invite participants to shape the process conceptually. It was used at strategic moments of the project, first in the beginning, whilst the mapping and surveying took place, introducing the project and research questions and inviting innovative knowledge sharing through interactive roundtable discussions; and later, once focus groups have been completed to share findings and to invite further reflection and elaboration on key themes that have emerged. From the above description, it should become clear that we made an attempt to let different methods build upon each other, whilst at the same time trying to fuse them creatively.

Interactive research and dialogue approaches emphasising facilitative and leadership involvements by the local residents whose contexts are being researched have gained increasing support amongst academic and public policy sector researchers. Community-driven and community participatory research strategies increasingly have attempted to respond more effectively to historic criticisms (emanating especially from marginalised communities who have been targeted for research) about research exploitations of their communities. For example, DataCenter, an activist global research network, library and publication centre, stresses a 'research justice' framework that believes marginalised communities 'should be recognised as experts, and reclaim, own, and wield all forms of information' related to their contexts (DataCenter). The research project outlined in this article draws on similar sensibilities, as did the Morehouse College-based mixed methods neighbourhood study directed by one of this article's co-authors (Smith 2003).

This article explores benefits as well as gaps in the utilisation of these standard and creative research methods in discerning and delineating religious innovation in these urban South African contexts.

\section{Trans-disciplinary approaches: A self-critical description and assessment}

Our research team consisted of people with backgrounds as systematic and practical theologians, missiologists, urbanists and a political scientist. We are full-time academic researchers and practitioners. We were shaped by black and liberation theologies, narrative theory, critical race theory and studies in community transformation. Theoretically, we were very much shaped by participatory action from below, despite not this approach in the research project with the kind of depth we would have liked. Part of our reflection in this article is to explore reasons for this, whilst also charting the way for a next phase of the project. 


\section{Participatory or collaborative discovery and construction of knowledge}

Reason and Bradbury (2001) speak about the action research as:

a participatory democratic process concerned with developing practical knowing in the pursuit of worthwhile human purposes, grounded in a participatory worldview which we believe is emerging at this historical moment. (p. 1)

The intention in our research project was to work in such a participatory way, and the methods were deliberately chosen with this in mind. To some extent, this happened but our assessment at the end of this phase of the project was that the participatory and collaborative nature of the project remained rather superficial.

Firstly, we probably erred on the side of that which some of us often critique, namely to embrace a certain approach theoretically (orthodoxy) but failing to embody it concretely in how it finds worked out in practice (orthopraxy).

Secondly, the tight timeframes and project goals were not properly considered when we conceptualised the project. A project of this nature required deeper immersion of the researchers in the two regions, in order to build solid relationships of trust over time that would result in shared ownership of the project. As we enter a next phase of the project, we would make sure to immerse ourselves deeper, and to involve local coresearchers much more intentionally from the onset.

Thirdly, whilst not our intention, not enough was done to consolidate long-term relational activities between our research team and persons in the research contexts, nor to ensure that the 'researched' are becoming the agents and coconstructors of knowledge generated about 'them'.

\section{Collaborative knowledge generation}

One of the key characteristics of a trans-disciplinary approach is collaborative generation and sharing of knowledge. Although we were using the structure of the praxis cycle, our processes were probably not adequately participatory, coowned by co-researchers - or local church communities - and therefore not truly collaborative. From one angle, the collaborative methods built into the process ended up being rather superficial because of a lack of sufficient immersion. At the same time, co-researchers were neither aware of our use of the praxis-cycle nor were most of them probably with the praxis-cycle. A sincere desire for collaborative knowledge generation should perhaps be preceded and/or accompanied by a process of exposing people to the praxis cycle as a method for performing theology locally. On the other hand, the participative methods that we used surfaced important data which we would like to further engage in ongoing research processes and conversations.

Nevertheless, strengths we can point to in our research approach include combining literature study with mapping, surveys, focus groups and World Cafés. Church leaders from both Pretoria Central and Mamelodi East were invited to World Cafés in April 2016 before the actual field work started. This provided a solid base of local insight and experiences upon which to build. Towards the end of the research process, another World Café was hosted in April 2017 with leaders from both regions, providing feedback on initial findings, sharing information and inviting critical discussion and feedback. This World Café helped to shape the content and format of the final colloquium. The colloquium was arranged in June 2017, and, in true trans-disciplinary fashion sought to create an innovative space for the sharing of different kinds of knowledge between the research team, church leaders, faith- and community-based leaders from both regions and others. The colloquium was designed to surface the most important research findings, articulate new research questions, acknowledge and articulate possible signs of hope and considered possibilities going forward.

A representative sample of church leaders, covering the broad spectrum of Christian traditions, was invited to attend the World Cafés. The initial World Cafés had small but diverse groups of participants, sharing insights that helped describe their own regions well. The initial World Cafés were followed by a mapping process in both areas, identifying 97 churches -57 churches in a defined area of Pretoria Central and 40 churches in Mamelodi East, within a $1 \mathrm{~km}$ radius around the Mamelodi Campus of the University of Pretoria.

The mapped churches formed the basis of our research and we invited these churches to participate in a survey. A total of $37.10 \%$ of mapped churches participated in the survey that provided us with very rich baseline information. Information focused on composition of the church in terms of gender, race, nationality, age and income levels; questions on leadership, tradition and vision of the church; as well as information describing how the specific church view local contextual challenges and how it responded to such challenges as a church. The initial surveys were not completed congregation-wide but were sourced through a simple, limited question survey, filled in by a key leader of the congregation.

Once a picture emerged of the area, six groups per region (12 in total) were selected for more in-depth engagement through focus groups and unstructured interviews. Groups surveyed and selected for more in-depth engagement included churches coming from diverse church traditions and representing a diversity of compositions. The more in-depth engagement focused more specifically on the research questions and on issues of religious innovation and religious competition, in relation to urban change and urban vulnerability.

\section{Searching for a liberating, trans- disciplinary research methodology}

Although we set out to do research that would be praxisbased, collaborative and optimising benefits for the communities in which we did the research, it soon became 
clear to us that there were disconnects between what we set out to do and what we were able to do, given both the time constraints but also our own constraints and limitations in relation to rigorous empirical work in an authentically participatory manner. We recognise the limitations of our paradigms and approaches, profoundly shaped as they are by the global. We need new languages, new methods and tools for enquiry, a new consciousness with which to approach both the urban communities to be researched and the research itself.

This article is therefore an attempt to be self-critical but not in a self-defeating way. Instead, we would like to outline a possible methodology that moves closer towards a liberating approach of conducting research on religious expression in urban Africa.

\section{Delving deep and beyond}

Through our research engagement, we hoped to cultivate deeper self-critical reflection and a more assertive articulation of local knowledge. Both the tight time frames and overambitious research objectives worked against deep knowledge generation. In the next phase of the project, we would like to build on the relationships that were formed, however, tentative, to delve much deeper.

We will seek to be truer to a trans-disciplinary approach; shaped more directly by the questions, concerns and aspirations coming from local churches themselves; and desirous of seeing our research contributing more directly and more concretely to local urban change.

Some of our research team had substantial immersions in Pretoria Central over many years. Only one member of our team had comparable experience of Mamelodi. We realised that our readings of Mamelodi will remain very superficial if we fail to deepen our own immersions in this context.

\section{Research as emancipation or conscientisation}

Building on our commitment to a participatory process of research, discovering and constructing knowledge together and seeking to delve deep and beyond what we knew up to this point, we would like to explore research as emancipation (cf. Nkoane 2012; Schwartz 2011) or theology as conscientisation (Allen 2008; Freire 1970; Glassman \& Erdem 2014) going forward. Emancipatory research refers to the kind of research that involves the 'researched' in such a way as co-researchers or carriers of own authentic knowledge that, through the research process, agency is built, people find an own voice, their questions shape the research question, their knowledge contributes to new knowledge generated and they are left with a sense of being empowered, or emancipated, instead of being exploited through disrespectful extraction of their knowledge and information.

Delving even deeper would be to retrieve from the insights and commitments of liberation theologies. Allen (2008) speaks about liberation theology's '[ $r$ ]ecognition of the capacity of the poor to engage in the process of changing their circumstances'. They do that, say Boff and Boff (1987:5), through 'coming together, coming to understand their situation through the process of conscientization, discovering the causes of their oppression, organizing themselves into movements, and acting in a coordinated fashion'. Oppression often has a paralysing effect on people, internalising their oppression and becoming victims, helpless or even to-beblamed. The way out of such powerlessness or paralysis, says Freire (1970), is through a process of conscientisation. Theology and research as conscientisation, in urban communities marked by deep and often generational vulnerabilities, will be collaborative processes in which researchers and community members together develop an understanding of a situation, discover causes that created or perpetuate a situation and foster an imagination of alternative possibilities, and embracing and building own agency to effect such new and liberating possibilities.

\section{Surveys}

We have found the process of surveying and focus groups more challenging than anticipated. There are a number of reasons we realised, some clear and some more speculative:

- People find the survey forms more difficult to complete than anticipated, either because they take the process quite seriously, or because there is information requested that they might not be willing to part with.

- The survey forms, in particular, show gaps in questions dealing with issues such as finances, funding or administration: respondents either hesitate or leave these questions blank. This is especially the case where churches are more informal, perhaps indicating the challenge they themselves face in relation to financial or administrative management; or, in some cases, a more deliberate lack of accountability or transparency (although we cannot prove that).

- We also had a real sense that some churches were hesitant to participate because of the rather newly formed Commission for the Promotion and Protection of the Rights of Cultural, Religious and Linguistic Communities (South African Constitution, Act of 2002). The work of this commission, amongst other things, is to investigate the 'commercialisation' of religion and religious practices, and to monitor and address the abuse of people by religious institutions. Churches might have legitimate or unfounded concerns about the work of this commission, depending on their own practices and governance, but our sense was that there is great caution amongst churches in terms of exposing themselves to 'outside' people.

Although the survey forms provided valuable information, the depth of discovery and possibilities for shared knowledge generation are rather limited. For an approach that is more liberating, the nature of survey questions might have to be reconsidered in order to facilitate more self-reflection with respondents; the survey form might be used as part of a more participatory process in which respondents could reflect 
together on their own responses, and in community with other churches; or the survey form could be replaced by structured or open-ended interviews that might be better suited for a more participatory or relational approach to research.

\section{Focus groups}

We discerned possible tensions from several hierarchically inclined pastors and church leaders, uncomfortable with inclusive research approaches that grouped leaders and ordinary members together in discussions. In one focus group, the pastor made all the arrangements for the focus group, but once the dialogue was about to start, he left the room and waited outside in his car for the discussion to be completed.

We might not have prepared the spaces and participants well enough. Even if the researchers themselves are committed to a research approach that is very participatory, a hierarchical church structure will provide serious challenges to the actual process, as indicated above. A slower, longer term process, growing out of deeper local relationships, might also enhance both the quality and depth of focus group conversations, for researchers and co-researchers (focus group participants) alike. It will allow for deeper and more honest (self)-reflection, which is a prerequisite for emancipation or conscientisation.

\section{Mapping}

We realised that we undervalued the potential of mapping as a participatory research method in urban neighbourhoods. Instead of reducing it to an administrative technique to establish baseline information only, which is in itself important too, we would like to explore the liberatory or emancipatory potential of socio-spatial mapping (Natarajan 2015; Smith 2010; Takahashi 1997; Walks 2001) and participatory action mapping (Boll 2015; Chambers 2006; Literat 2013).

Natarajan (2015) highlights the importance of local knowledge in socio-spatial strategy-making. Without inviting such knowledge - embedded in local communities, people and organisations - as part of participatory socio-spatial mapping and planning processes, knowledge constructs remain rooted in skewed power relations and participation becomes mere tokenism.

In Boll's (2015) use of participatory action mapping as critical mapping methodology, some neighbourhood participants spoke about how this method helped conscientise them, not only in terms of how the city-based decisions about their neighbourhoods on wrong maps, but also in terms of seeing and affirming what they themselves knew, and building new-found agency and capacity on the basis of their own expressed knowledge.

Literat (2013:198-216) demonstrates how participatory mapping of their socio-spatial environments help empower young people: through active participation in the representation and explication of their environment, by themselves, young people are empowered with critical reflective skills and a critical consciousness. They find an own voice and shape the discourse about their environment on their own terms and in their own language. Participatory mapping processes contribute to generating knowledge collaboratively and in community, and holds potential to become a local resource for information sharing, organising communities, collective planning and collaborative action.

\section{World Café}

Earlier, we described our use of the World Café as a participatory research method in our research process. As with participatory mapping, the World Café is deliberate in its appreciation of local knowledge, inviting it to be shared in a deeply collaborative meaning making process (cf. Steier, Brown \& Da Silva 2015:212).

\section{The World Café is:}

a simple yet powerful conversational process that helps groups of all sizes to engage in constructive dialogue, to build personal relationships, and to foster collaborative learning. (Tan \&Brown 2005)

For a World Café to be a space that offers quality and depth of engagement, it is important to prepare the space rather deliberately with a number of key elements in mind: setting the context cafestyle; creating hospitable space; exploring questions that matter; encouraging everyone's contribution; cross-pollinating and connecting diverse perspectives; listening together for patterns, insights and deeper questions; and harvesting and sharing collective discoveries (Steier et al. 2015:215-218). It is not a rigid but dynamic space with ongoing movement around tables allowing for depth of interaction and knowledge sharing.

Some of the research team has participated in World Café style consultations before, but it was the first time for any of the members to use it as a research method. Once again, more time and better preparation, as well as more practice in the actual dynamics of hosting a World Café well, will ensure optimum participation and help gather and consolidate a broad base of knowledge, experience and insight. The nature of the World Café asserts the value of each participant's presence, importance, equality, experience and knowledge. That in itself, the way in which their contributions are invited and the collective process of meaning-making hold great promise to serve an emancipatory or conscientising agenda.

\section{Conclusion}

In this article, we reflected on a specific research project in the City of Tshwane. We provided self-critical reflections on the research process and methods employed. Our self-critical reflections prompted us to delve beyond what we knew and did before, in search for a liberating, trans-disciplinary research methodology and the most appropriate methods for researching faith and religious expressions in urban Africa. 
A first moment in a liberationist praxis is to be deeply immersed in a local community or situation. Searching for a liberating research methodology without much more deliberate immersion(s) would be a contradiction. Similarly, searching for a trans-disciplinary research methodology without much more deliberate collaboration with those researched, throughout the research process - from inception to conclusion and beyond, as well as with other disciplines engaging similar research topics, would be untrue to what is different about this paradigm.

We hope to be immersed and collaborating in more authentic and creative ways, as we seek to build new urban knowledge regarding the ways in which churches heal or perpetuate urban fractures. In the process, we hope that communities of research will emerge that can contribute to urban liberation or transformation in much more tangible ways.

\section{Acknowledgements}

The project was funded by the Templeton Foundation as part of an Africa-wide enquiry on 'Christianity and social change in contemporary Africa'.

\section{Competing interests}

The authors declare that they have no financial or personal relationships which may have inappropriately influenced them in writing this article.

\section{Authors' contributions}

S.F.d.B., R.D.S. and J.M. equally contributed to the research and writing of this article.

\section{References}

Allen, J.D., 2008, 'The intersection of liberation theology, structural social work, and empowerment practice', Presented at the Third North American Conference on Spirituality and Social Work, St. Thomas University Fredericton, Nebraska, 19th21st June.

Berger, P., 1967, The Sacred Canopy: Elements of a sociological theory of religion, Doubleday, Garden City, NY.

Boff, L. \& Boff, C., 1987, Introducing liberation theology, Orbis Books, Maryknoll, NY.

Boll, A.J., 2015, 'Cartography for communities: An examination of participatory action mapping', Unpublished Masters dissertation, Georgia State University.

Chambers, R., 2006, 'Participatory mapping and geographic information systems: Whose map? Who is empowered and who disempowered? Who gains and who loses?', Electronic Journal of Information Systems in Developing Countries 25(2), 1-11.
Commission for the Promotion and Protection of the Rights of Cultural, Religious and Linguistic Communities (CRL Rights Commission), 2002, (Act of 2002).

DataCenter, viewed 18 March 2017, from http://www.datacenter.org/

De Beer, S., 2014, 'Whose knowledges shape our city? Advancing a community-based urban praxis', De Jure2(47), 218-223.

De Beer, S. \&Swart, I., 2014, 'Towards a fusion of horizons: Thematic contours for an urban public theological praxis-agenda in South Africa', HTS Teologiese Studies/ Theological Studies 70(3), Art. \#2812, 1-9. https://doi.org/10.4102/hts.v70i3.2812

Freire, P., 1970, Pedagogy of the oppressed, transl. M.B. Ramos, Herder, New York.

Glassman, M. \& Erdem, G., 2014, 'Participatory action research and its meanings: Vivencia, praxis, conscientization', Adult Education Quarterly 64(3). https://doi. org/10.1177/0741713614523667

Hankela, E., 2014, 'Faith community as a centre of liberationist praxis in the city', HTS Teologiese Studies/Theological Studies 70(3), Art. \#2768, 1-9. https://doi.org/ 10.4102/hts.v70i3.2768

Holland, J. \& Henriot, P., 1983, Social analysis: Linking faith and justice, Dove Communications, Maryknoll, NY.

Huchzermeyer, M., 2011, Cities with 'slums': From informal settlement eradication to a right to the city in Africa, Juta/UCT Press, Cape Town.

Literat, I, 2013, 'Participatory mapping with urban youth: The visual elicitation of socio-spatial research data', Learning, Media and Technology 38(2), 198-216. https://doi.org/10.1080/17439884.2013.782037

Milbank, J., 2006, Theology and social theory: Beyond secular reason, Wiley-Blackwell, Hoboken, NJ.

Natarajan, L. (ed.), 2017, 'Socio-spatial learning: A case study of community knowledge in participatory spatial planning', Progress in Planning 111, 1-24. https://doi. org/10.1016/j.progress.2015.06.002

Nkoane, M.M., 2012, 'Critical emancipatory research for social justice and democratic citizenship', Perspectives in Education 30(4), 98-104.

Pieterse, E., 2014, 'Epistemological practices of Southern urbanism', Paper presented at the ACC Academic Seminar, University of Cape Town, Cape Town, 21st February.

Rakodi, C., 2014, 'Religion and social life in African cities', in S. Parnell \& E. Pieterse (eds.), Africa's urban revolution, pp. 82-109, Zed Books, London.

Reason, P. \& Bradbury, H. (eds.), 2001, Handbook of action research: Participative inquiry and practice, Sage, London.

Schwartz, S., 2011, “"Going deep" and "giving back": Strategies for exceeding ethical expectations when researching amongst vulnerable youth', Qualitative Research 11(1), 47-68. https://doi.org/10.1177/1468794110385885

Smith, A., 2010, 'Social/spatial mapping of asylum seeker accommodation centres in Ireland', Geographic Information System (GIS) Interactive Website, viewed 18 March 2017, from http://www.unbc.ca/anthropology/smith_research_asylum_ seekers.html

Smith, R.D., 2003, Beyond the boundaries: Low income residents, faith-based organizations, and neighborhood coalition building, The Annie E. Casey Foundation, Baltimore, MD.

Steier, F., Brown, J. \& Mesquita da Silva, F., 2015, 'The world cafe in action research settings', in $\mathrm{H}$. Bradbury (ed.), The SAGE handbook of action research, 3rd edn., pp. 211-2019, Sage, Thousand Oaks, CA.

Takahashi, L.M., 1997, 'The socio-spatial stigmatization of homelessness and HIV/ AIDS: Toward an explanation of the NIMBY syndrome', Social Science\& Medicine45(6), 903-914. https://doi.org/10.1016/S0277-9536(96)00432-7

Tan, S. \& Brown, J., 2005, 'The world café in Singapore', Creating a Culture through Dialogue 41(1), 83-90.

Walks, R.A., 2001, 'The social ecology of the post-fordist/global city? Economic restructuring and socio-spatial polarisation in the Toronto Urban Region', Urban restructuring and socio-spatial polarisation in the Toronto Urban Region
Studies 38(3), 407-447. https://doi.org/10.1080/00420980120027438

Winkler, T., 2008a, 'Super-sizing community development initiatives: The case of Hillbrow's faith sector', International Journal of Public Theology 2(1), 47-69. https://doi.org/10.1163/156973208X256448

Winkler, T., 2008b, 'When God and poverty collide: Exploring the myths of faithsponsored community development', Urban Studies 45(10), 2099-2116. https:// doi.org/10.1177/0042098008094875 